Original scientific article/Izvirni znanstveni članek

\title{
The contribution of ethnography to understanding nursing work: a comparative review of three nursing ethnographies \\ Prispevek etnografije $\mathrm{k}$ boljšemu razumevanju dela medicinskih sester: primerjalna ocena treh etnografij $\mathrm{v}$ zdravstveni negi
}

Fiona Murphy, Pauline Griffiths, Joy Merrell

\begin{tabular}{|c|}
\hline $\begin{array}{l}\text { Key words: participant } \\
\text { observation; research methods; } \\
\text { intensive care; gynaecology; } \\
\text { medical admissions }\end{array}$ \\
\hline $\begin{array}{l}\text { Ključne besede: opazovanje z } \\
\text { udeležbo; raziskovalne metode; } \\
\text { intenzivna nega; ginekologija; } \\
\text { nujni sprejem bolnika }\end{array}$ \\
\hline $\begin{array}{l}\text { Fiona Murphy, PhD, MSc } \\
\text { (Nursing), BN, RGN, NDN, } \\
\text { RCNT, PGCE(FE), Associate } \\
\text { Professor, College of Human } \\
\text { \& Health Sciences, Swansea } \\
\text { University, United Kingdom } \\
\text { and Associate Professor of the } \\
\text { College of Nursing Jesenice, } \\
\text { Slovenia } \\
\text { Correspondence e-mail/ } \\
\text { Kontaktnie-naslov: } \\
\text { f.murphy@swansea.ac.ul }\end{array}$ \\
\hline $\begin{array}{l}\text { Pauline Griffiths, PhD, } \\
\text { MSc (Nursing), RN, PGCE, } \\
\text { Postgraduate Diploma in } \\
\text { Health Care Law, Associate } \\
\text { Professor, College of Human } \\
\text { \& Health Sciences, Swansea } \\
\text { University, United Kingdom }\end{array}$ \\
\hline $\begin{array}{l}\text { Joy Merrell, PhD, MSc } \\
\text { (Nursing), BSc (Hons) Nursing, } \\
\text { RGN, RHV, RNT, HV Tut Cert, } \\
\text { Professor, College of Human } \\
\text { \& Health Sciences, Swansea } \\
\text { University, United Kingdom } \\
\text { and Associate Professor of the } \\
\text { College of Nursing Jesenice, } \\
\text { Slovenia }\end{array}$ \\
\hline
\end{tabular}

\section{ABSTRACT}

Introduction: This methods paper examines ways in which ethnography and in particular the ethnographic method of participant observation, informs understanding of the reality of nursing work. Methods: The relevance of ethnography for nursing practice is illustrated through three ethnographic studies of nursing work, all of which involved participant observation for periods of over twelve months. These studies were conducted in three different hospital settings in Wales, United Kingdom; an intensive therapy unit, a gynaecological unit and a medical admissions unit. Definitions of ethnography are considered along with an account of three key ethnographic methods; participant observation, interviews and documentary analysis.

Results: Two key themes which were apparent in all three of these ethnographies will be presented to demonstrate the contribution of ethnography in understanding nursing practice. These themes are; the embodied nature of nursing work and duality and tension in nursing work.

Discussion and conclusion: It will be argued that ethnography as a research approach enables nursing practice to be understood as it is actually experienced in the uncertain, disruptive and often resource limited context of contemporary healthcare.

\section{IZVLEČEK}

Uvod: Prispevek o raziskovalnih metodah predstavlja vlogo etnografije in še posebej etnografski proces opazovanja, odkrivanja in razumevanja področja zdravstvene nege $\mathrm{z}$ udeležbo opazovalcev.

Metode: Avtorice utemeljujejo pomen etnografije za delo medicinskih sester z izsledki treh etnografskih empiričnih raziskav $\mathrm{z}$ udeležbo opazovalcev. Raziskave so potekale eno leto $\mathrm{v}$ treh različnih bolnišničnih okoljih v Walesu (Združeno kraljestvo) - na oddelku za intenzivno nego, na ginekološkem in sprejemnem oddelku. Raziskava sledi principom etnografske metode kvalitativnega raziskovanja, kjer je ključnega pomena opazovanje kulturnih obeležij z udeležbo, izvajanje intervjujev in analiza dnevnih zapisov, kar omogoča poglobljeno razumevanje ljudi in vpogled v družbeni in organizacijski kontekst.

Rezultati: Rezultati raziskave opozarjajo, da lahko etnografija pripomore k boljšemu razumevanju vsakodnevnega dela medicinskih sester, predvsem zaradi narave dela ter dvojnosti in nasprotij, ki sta ključni značilnosti zdravstvene nege.

Diskusija in zaključek: Uvajanje etnografskih metod raziskovanja se utemeljuje z novim razumevanjem zdravstvene nege v praksi, ki se odvija v negotovem, nepredvidljivem okolju zdravstvene oskrbe, ki ga pogosto zaznamuje tudi pomanjkanje ustreznih kadrovskih in finančnih virov. 


\section{Introduction}

Although there is much debate as to a definition; ethnography as a research approach can be described as the direct description of a group, culture or community (Holloway \& Wheeler, 2010, p. 153). It sits within the qualitative end of the research continuum and has its roots in anthropology. The ethnographer studies the culture, community or group in depth through observing and directly participating in their activities with a view to understanding what meanings people attach to what they do and say. The goal of ethnography is to offer a description or 'a sociological synthesis' (Malinowski, 1922, p. 81) to identify, interpret and understand the culture and context under study.

In this paper it will be argued that from a nursing research perspective, ethnography as a research approach has a valuable contribution to make in understanding nurses, nursing care and the culture of care settings. Insights generated from ethnographic research are crucial in order to make changes to improve patient care. Ethnography has made a significant contribution to nursing research in the later years of the last century, for example, Wolf, (1988); Smith, (1992); Street, (1992); Porter, (1995); Savage, (1995). However, a search of the following databases: CINAHL; ASSIA; Pubmed and British Nursing Index for research based articles published over the last decade, (terms ethnograph ${ }^{\star} /$ nurs $^{\star} /$ research method) indicates that this approach is becoming less prominent in more recent nursing research. Although this preliminary search elicited many articles described as 'ethnography', closer examination revealed that few, although there were clearly exceptions, had used participant observation, arguably ethnography's defining feature (Delamont, 2007). In this methods paper, three recent and different ethnographies of nursing work in United Kingdom (UK) hospitals will be drawn on to demonstrate the contribution of an ethnographic research approach to understanding nursing practice. The first ethnography (Philpin, 2007) is of the social world of nurses working in an Intensive Therapy Unit (ITU). The second ethnography (Murphy \& Merrell, 2009) explored the management and care of women having an early miscarriage in a hospital gynaecological unit. The final ethnography (Griffiths, 2011) explored nurses' roles in an acute medical admissions unit (MAU). All three studies were authored by nurses, examined nursing work and used broadly similar approaches to the ethnographic method. These three studies were part of a programme of linked $\mathrm{PhD}$ studies within one United Kingdom Higher Education Institution, two of which were supervised by the same supervisor. The programme was focused on examining nursing work using an ethnographic approach influenced by the British ethnographers Martin Hammersley and
Paul Atkinson (Hammersley \& Atkinson, 2007). The underlying research aims, methodology and methods of the three studies thus were similar in nature. All incorporated a prolonged period of participant observation, interviews with key informants and analysis of documentary evidence in the setting. The analysis of these three ethnographies of nursing work called attention to the way in which participant observation and prolonged immersion in the practice setting is uniquely placed to uncover aspects of the nature of nursing practice and how culture and context shapes that practice. A case is presented for the contribution of ethnography as a research approach to understand nursing work, through drawing on selected findings of these three nursing ethnographies. The paper begins with defining ethnography and a general overview of ethnographic research methods including an account of the methods used in the three studies. A comparison of the findings of the three studies identified some common themes and these are drawn on to illustrate the contribution of ethnography as a research approach to gain an indepth understanding of nursing practice. These themes are firstly, the embodied nature of nursing work and secondly, duality and tension in nursing work.

\section{Defining ethnography}

There is a lack of consensus over the meaning of ethnography which is partly explained as its origins were in early $20^{\text {th }}$ century social anthropology and later sociology (Hammersley \& Atkinson, 2007). In Europe, ethnography developed from social anthropology and was closely aligned with British colonialism. In North America the influential Chicago School signalled a move away from this type of cultural anthropology to use observation to explore marginalized urban groups (Brewer, 2000). 'Ethnography' therefore encompasses a number of different concepts and there are also differing ideas as to the nature of its key elements (Brewer, 2000). 'For some [ethnography] refers to a philosophical paradigm to which one makes a total commitment, for others it designates a method that one uses as and when appropriate. And, of course, there are positions between these extremes' (Atkinson \& Hammersley, 1994, p. 248).

Despite a lack of consensus, most understandings of ethnography make reference to gaining access to the social meanings of the people studied. The central tenet is participant observation over a prolonged period 'watching what happens, listening to what is said, and/or asking questions through informal and formal interviews, collecting documents and artefacts' (Hammersley \& Atkinson, 2007, p. 3). The meaning and purpose assigned to ethnography is also informed by the particular ontological approach of the researcher. The ethnographies in this paper 
were all premised on Hammersley's (Hammersley, 1992) ontological position of subtle realism. From this perspective, the aim of social research is to represent reality 'from some point of view which makes some features of the phenomena relevant and others irrelevant. Thus, there can be multiple, noncontradictory and valid descriptions and explanations of the same phenomenon' (Hammersley, 1992, p. 51).

Another key feature of ethnography is to provide a cultural description of the group studied. However, culture, like ethnography, is a contested term and the three studies utilised Geertz's early, and much quoted, explanation of culture:

'The concept of culture I espouse... is essentially a semiotic one. Believing, with Max Weber, that $\operatorname{man}_{\text {sic }}$ is an animal suspended in webs of significance he himself has spun, I take culture to be those webs, and the analysis of it to be therefore not an experimental science in search of law but an interpretive one in search of meaning' (Geertz, 1993, p. 5).

It was intriguing to unravel the meanings in the 'webs of significance' in these particular nursing areas and the ways in which ethnographic methods facilitated this will now be outlined.

\section{Ethnographic methods}

Ethnographers employ multiple methods of data collection but often utilise three main methods; participant observation through prolonged immersion in the field, in-depth interviews with key informants and analysis of documentary material. A general overview of these methods and their use in ethnography will be presented followed by a more specific account of how these methods were used in the three studies.

\section{Participant observation}

Participant observation is, arguably, the underpinning principle of ethnography; indeed Delamont (Delamont, 2007, p. 206) refers to 'proper ethnography; that is participant observation done during fieldwork'. 'It involves data gathering by means of participation in the daily life of informants in their natural setting: watching, observing and talking to them in order to discover their interpretations, social meanings and activities' (Brewer, 2000, p. 59). Observation can be overt or covert in nature in that the role of the researcher is either known (overt) or unknown (covert) to the people in the setting.

One further salient feature of ethnography which ensures its contribution to the analysis of nursing work is prolonged immersion in the field through this participant observation (Delamont, 2007). Brink and Edgecombe (2003, p. 1028) note that there has been an increasing 'bastardization' of ethnography when researchers claim to have used ethnography without its 'signature' research design: the observation of human behaviour within a culturally and socially defined context. Thus an important indicator of the validity of an ethnographic study is the period of time spent observing in the field. The aim is to spend a prolonged period immersed in the field in order to offer an interpretation of the culture and an understanding of the complexities of the setting. Ethnographers speak of being 'in the field' with the 'field' being the setting or context in which the ethnographer collects data. Thus 'field notes' are an important part of data collection in ethnography. Whilst working and observing in the field, notes are taken on the events that are occurring and are written as soon as possible to ensure an accurate recording of these events (Gobo, 2008).

\section{Interviews}

A second data collection method used in ethnography is in-depth interviews with key informants. Interviews have been described as a common method of data collection in qualitative research and are conversations directed usually by the researcher to achieve the research aims (Green \& Thorogood, 2013). For Mason (2002), the conduct of an interview in a qualitative study should be informal, focused on the interaction and congruent with the ontological and epistemological position of the researcher. As Green and Thorogood (2013) identify, the interview is an account of a phenomenon, which is open to interpretation by the researcher.

As Hammersley and Atkinson (2007) highlight, interviews in ethnographic research range from informal conversations in the field to organised specific face to face encounters. Thus the ethnographic interview is situated and contextual with the researcher being considered as the instrument of data collection (Brewer, 2000; Mason, 2002; Green \& Thorogood, 2013).

\section{Documentary evidence}

A third key method of data collection used in ethnography is analysis of documentary evidence. As Prior (2003) suggests, it is difficult to precisely define what is meant by a 'document', but it can be considered as written text used as data. In literate cultures, Hammersley and Atkinson (2007) state that ethnographers need to take account of documents as part of the social setting under investigation. This is because as Mason (1996, p. 72) suggests, they are 'meaningful constituents of the social world in themselves' but should be interpreted with care. Again, as in observation issues of selectivity and perspective arise. Mason (1996) further suggests a need to be critical in the analysis of any text and recognises the fact that researchers interpret and make critical judgements as to what they attend to. 


\section{Aims and objectives}

This methods paper examines ways in which ethnography and in particular the ethnographic method of participant observation, informs understanding of the reality of nursing work.

\section{Methods}

In all three studies, the ethnographic methods of participant observation, interviews and review of documentary evidence were used. In all, the methods were theoretically informed by an ethnographic methodology, incorporating reflexivity and attention to context.

A principle of reflexivity is 'that researchers should subject their own research practice to the same critical analysis that they deploy when studying their topic' (Green \& Thorogood, 2013, p. 23). The ethnographer needs to be aware that factors such as their age, gender, social class and occupation might influence how they collect and interpret the data.

\section{Participant observation}

In these studies the researchers' role as observer was overt in that the researcher 'participated' in the nursing work. This was achieved by 'shadowing' and working alongside nurses throughout the course of their shift. Although the roles were principally of observersas-participant (Gold, 1958), as registered nurses the researchers adopted a secondary role as 'helper' to the nurses where appropriate. Whilst shadowing one nurse or working with the nurses there was interaction with the rest of the healthcare team and the patients for whom they provided care. In all three studies the period of participant observation lasted for at least one year.

'Reflective' journals were also kept by all three researchers. These were personal accounts of the research experience, starting from when the research questions were first formulated and continuing throughout the data collection and analysis stages. They were also used to record any ideas, thoughts and feelings that occurred in and out of the field, especially the researchers' reactions (and reactions sensed from other people) to situations and events. This proved invaluable as a basis for reflexivity on the research experiences.

\section{Interviews}

All three studies included audio recorded, individual interviews with nurses with Authors 1 and 2 also interviewing other key informants such as patients and other healthcare professionals. In all three studies, reflective notes describing the context of each interview were made. The interviews were semi-structured and reflexive, in that the questions were informed by a review of the literature and based on a series of issues that had arisen from the on-going early analysis of the observational data.

\section{Documentary evidence}

Written texts, some highly visible, such as notices, patients' charts and nursing care plans and others, such as patient records, more hidden, were much in evidence in all three research settings. As with participant observation, these documents were studied, both in terms of their substantive content and their context that is such things as their positioning and authorship, the ways in which they were used and how much attention was paid to them (Prior, 2003).

Whilst the three studies used all of these methods, the focus here is on the essential utility of participant observation in understanding the realities of nursing practice.

\section{Data analysis}

Analysis in ethnographic studies is a reflexive activity that starts as research questions are formulated and continued throughout (and underpinned) data generation and the writing up stage (Hammersley \& Atkinson, 2007). In the studies, thematic analysis (Green \& Thorogood, 2013) was used and emerging themes were analysed in relation to relevant literature. In each study analytic rigour was enhanced through reflexive awareness of the relationship between the researchers and participants and also between the authors and their final written texts or accounts. Moreover, reflexive awareness of reactions - physical, emotional and mental - to events in the field, contributed to the analysis.

\section{Ethical considerations}

All three studies were formally reviewed by the UK National Health Service institutional ethics committees and formal ethical approval was obtained. The researchers were all registered nurses and thus adhered to the UK Nursing and Midwifery Council (Nursing \& Midwifery Council, 2008) Code of Conduct.

\section{Results}

\section{The contribution of ethnography to understanding nursing work}

To illustrate this contribution, two key themes which were common to all three studies are discussed now. These are the embodied nature of nursing work and duality and tension in nursing work.

\section{The embodied nature of nursing work}

In all three studies, the ability to engage with participants in a naturally occurring context and then to interpret and explore the meanings of this observed behaviour within an ethnographic 
framework gave insights into the complexity of nursing work (Gerrish, 2003). Whilst in the field, the researchers acted as observers and as helpers to the nurses. These observer/helper roles were intertwined inasmuch as whilst helping, the researchers were also physically experiencing the embodied nature of the nursing work (Savage, 2000; Delamont, 2007). By directly participating in the work the researchers as ethnographers experienced, through all of their senses, the world of the participants in the setting and although overwhelming at times, this sensory experience helped in the interpretation and analysis of the setting.

The use of the senses, including vision, smell, hearing and touch, was particularly relevant to the fieldwork experience in ITU; Philpin (2007) described a familiar smell hitting their nostrils - a warm, familiar, but anxiety-provoking mixture of disinfectant and unknown substances - on first venturing into the field. In addition the sounds in ITU - the almost constant 'bonging' of the various alarms (all emitting different sounds, recognisable to those who worked there), the bleeping of monitors if their sound was turned on and the quiet hiss of the ventilators; audible cues of the essence of the ITU, with its sense of busyness and urgency.

This use of senses other than visual includes the ways in which fieldwork is experienced by the physical body. The physical experience for all the researchers was an important part of the fieldwork, fatigue from early starts, aching backs from moving and bending over patients, and feelings of nausea from certain sights, sounds and smells.

All these sensory cues experienced by bodily immersion in the field also induced profound emotional responses in the researchers such as shock, sadness and fear which, on reflection, yielded greater understanding of the context and culture of this area in terms of what it meant for the people who worked there. In ITU, there was the shock of seeing extremely ill patients:

I feel shocked/sad/afraid to see a young man so ill. Bewildering array of equipment attached to him ventilator, haemodialysis tubes, various monitoring devices, $12 \mathrm{IV}$ infusions, naso-gastric feeding, arterial line - how does one keep track of it all? (Reflective journal excerpt ITU).

In the gynaecological unit, the researcher was struck by seeing the foetal body, (normally hidden from view) after miscarriage and terminations:

I looked in three special containers for foetal remains, two had fragments of placental tissue the third had an intact but dead 14 week foetus, which was really quite shocking, not something you would like to look at all the time (Field note extract gynaecological ward).

Whilst in the MAU setting, there were the deaths of patients, often unexpected with shocked families thus the confrontation with such raw grief was deeply affecting:
I helped care for a young man who was admitted with uncontrolled fitting related to drug and alcohol dependence. He was extremely thin and pale and just lay very, very still until he started fitting again. He was all alone. No family or friends were there to support him. I helped wash him and when I did this his frailness was evident when I touched him. To wash him gently was caring, as was the administration of intravenous medications he was receiving of course, but to touch him was to feel his vulnerability, his humanness and enabled a communication of caring (Field note extract MAU).

The participant observation meant that the researchers experienced these events themselves and reacted on an emotional level. As Wilkins notes, 'our emotional responses ... may have a sensitising, cognitive function which alerts us to the meanings and behaviours of others' (Wilkins, 1993, p. 96). Part of the process of fieldwork in all three studies was to move from these initial experiences, emotions and interpretations as researchers to an understanding of the perspectives of the participants who worked in and were familiar with these areas. Prolonged, embodied immersion in the field engendered alertness to the meanings and behaviours of others. The ethnographer repeatedly, physically experiences the context in which nursing is practised and through that comes to appreciate the meaning that the nurses might attach to that practice. This immersion in and observation of the field allowed such insights and understandings which might not be possible in other research approaches.

In addition to embodiment, all three ethnographies also identified duality and tension in nursing work which will be discussed now.

\section{Duality and tension in nursing work}

Participant observation and prolonged immersion in these fields yielded data which also identified duality and tension in nursing work. Examples from all three ethnographies are presented to illustrate this theme. In ITU, (Philpin, 2007) nursing work is underpinned by a rhetoric of rational evidence-based practice and the sensory experience of immersion in the field of an ITU leaves one in no doubt that this is a high-tech area 'par excellence'. The sounds of beeping monitors, 'bonging' alarms, swishing ventilators, talk amongst the staff and the visual cues of flashing monitors and observations of complex apparatus and procedures confirm this. Prolonged immersion in this setting however offered a more complex and contradictory picture of ITU nursing work, which included messiness and dangerousness. The high-tech surroundings of the ITU setting were in direct contrast with the very vulnerable and exposed human body, with nurses having to manage both. The researcher related how they physically felt the contradictory experience of nursing work in ITU as they steeled themselves to touch clammy skin or faces with strings 
of sputum and saliva around endotracheal tubes. These visceral and emotional experiences, which could not be entirely counteracted by science and technology, were important aspects of the field work experience in terms of making sense of what it meant to work in such a place.

Two more examples of duality and tension in nursing work identify a discrepancy between professional nursing rhetoric and the more pragmatic approach to nursing work that nurses employ. Contemporary expectations are that nurses should offer high levels of emotional care to their patients. Through participant observation and prolonged immersion in the field, it was noted that nurses found this very difficult to achieve all of the time. For example, in gynaecological nursing there are expectations that the nursing response to women having a miscarriage is to consider her as being bereaved and to offer sympathetic, emotional care (Swanson, 1991, 1999). When interviewed, nurses recognised that this was a very important aspect of women's care and one they sought to achieve. However, the prolonged periods of observation identified a contradiction between what the nurses said should happen and what appeared to be actually possible. The nurses interviewed, discussed the kind of emotional care that should be given yet other sources of data hinted at contradictions and discrepancies. Interviews with patients on the ward suggested that they were not receiving high levels of emotional care. In fact some felt abandoned and alone in the ward setting but made allowances for the nurses in recognising that they must be busy:

No, I think they were busy (laugh), they were busy and they'd seen it (miscarriage) I don't know how many times before ... (Jane, patient interview).
The field observations provided some explanation for these differing accounts between nurses and patients. It was evident that the nurses tended to give priority to those patients considered more ill and who had more pressing physical needs than women experiencing miscarriage. However, nurses expressed regret and concern that there was not always time to spend with patients:

I know once women go out into the ward, there's a very busy ward with a lot of people with very varying conditions and needs and they don't always erm... the nurses perhaps aren't just aren't able to give them the priority or the time that they might like to (Julie, nurse interview).

Similarly, on the MAU, time to provide emotional care was also in short supply and time for interaction with patients was rationed due to high workload demands. The pressure on beds and the need to move patients on rapidly also contradicted a nursing rhetoric that constructs a vision of a nurse engaging therapeutically with an individual's health needs over a prolonged time span (Watson, 1988). Nurses and patients noted the importance of effective communication as a key aspect of the MAU nurses' role, however in the time pressured MAU this was an ideal aspiration rather than a constant event. Eve, a 78 year old lady admitted with shortness of breath commented:

Well you see it is such a busy ward, nobody had time they were so busy and the people that were there were ill weren't they. I was lucky because I didn't need that sort of one-to-one attention. I could cope (Patient interview).

The nurses coped with such time limits on emotional care by presenting themselves in a friendly way whilst using evolved strategies to reduce patients' expectations, as illustrated in this example of one nurse's approach to new admissions:

Table 1. Summary of the methods used in the three studies

Tabela 1: Povzetek metod, uporabljenih $v$ vseh treh raziskavah

\begin{tabular}{|c|c|c|c|}
\hline & Study 1 (Philpin, 2007) & $\begin{array}{l}\text { Study } 2 \text { (Murphy \& Merrell, } \\
\text { 2009) }\end{array}$ & Study 3 (Griffiths, 2011) \\
\hline Aim of study & $\begin{array}{l}\text { Ethnographic exploration of } \\
\text { nursing culture in an intensive } \\
\text { therapy unit }\end{array}$ & $\begin{array}{l}\text { Ethnographic exploration of } \\
\text { the management and care } \\
\text { of women having an early } \\
\text { miscarriage within a hospital } \\
\text { gynaecology unit. }\end{array}$ & $\begin{array}{l}\text { Ethnographic exploration to } \\
\text { describe } \\
\text { and explain the role of the } \\
\text { Acute Medical Admissions } \\
\text { Unit nurse. }\end{array}$ \\
\hline Setting & Intensive Therapy Unit (ITU) & Hospital Gynaecological unit & $\begin{array}{l}\text { Hospital Medical Admissions } \\
\text { Unit }\end{array}$ \\
\hline Methods & $\begin{array}{l}\text { - } 12 \text { months part-time } \\
\text { participant observation. } \\
\text { - Interviews with } 15 \text { ITU } \\
\text { nurses. } \\
\text { - Review of key documents in } \\
\text { the setting. }\end{array}$ & $\begin{array}{l}\text { - } 20 \text { months part time } \\
\text { participant observation. } \\
\text { - Interviews with } 8 \text { women } \\
\text { experiencing miscarriage, } \\
10 \text { nurses, } 3 \text { doctors \& } 3 \\
\text { ultrasonographers working in } \\
\text { the unit. } \\
\text { - Review of key documents in } \\
\text { the setting. }\end{array}$ & $\begin{array}{l}\text {-18 months participant } \\
\text { observation. } \\
\text { - Interviews with } 19 \text { nurses, } \\
\text { doctors, patients, and } \\
\text { paramedics. } \\
\text { - Review of key documents in } \\
\text { the setting. }\end{array}$ \\
\hline
\end{tabular}


I pop in smile and say 'I will be along to see you shortly and here is an information leaflet. My name is Mary and any problems let me know'. It can be quite rushed but you do it in a calm way and sort of give the impression that you are there if they need you but your mind is everywhere once you have checked they are OK (Nurse Interview).

Nurses in these circumstances experienced conflict between espoused professional values and the reality of providing care. Nurses operated within the constraints of a system in both the gynaecological and medical admissions unit, which forced them to focus on more instrumental aspects of care to manage rapid patient throughput. Prolonged immersion in these fields made it clear that the nurses were required to work with limited resources that were defined institutionally rather than professionally led. This led to tension between an espoused theory of practice and that which was actually practiced. This tension between a rhetoric of professional caring that emphasises the emotions and the reality of actual practice is detrimental for both nurses and nursing (Allen, 2004).

\section{Discussion}

In drawing on these three ethnographies of nursing work, we argue that ethnography as a research approach is very useful to uncover the complexity of nursing work. Nursing is practised in many different settings, cultures and contexts all of which will influence the nature of the work. Nurses adjust their practice according to the setting in which they practice and within different settings particular cultural practices evolve. Ethnography and in particular prolonged, participant observation within the setting can help to uncover these practices and offer insights into the meaning and understandings that the nurses themselves attach to their work. It is also possible to identify insights and understandings from other significant people such as patients and other staff. An ethnographic analysis of all these perspectives particularly the observation data helps to reveal similarities as well as important differences in nursing as it is practiced in different settings. The strength of ethnography is a very clear and prolonged focus on a particular setting but in a holistic way in order to really understand what is going on. The insights generated from such an ethnographic examination can be very insightful for individual nurses examining their own practice as well as for administrators, educators and policy makers. Conducting participant observation over an extended period of time, in these three studies for more than a year, facilitated a deeper understanding of the complexity of factors which impacted on nursing work, for example, changes in staffing levels, and increased pressures on beds in the MAU due to increased demand on services during winter months. Observation over shorter time periods may not have yielded such insights.
We commented earlier in the paper, that ethnography as a research approach including observation seems to be less evident in nursing research. This paper has tried to demonstrate some of the strengths of ethnography, but it is also the case that ethnography presents challenges to researchers. Ethnography and within it participant observation is time consuming and presents numerous challenges in terms of resource use, ethical issues and the ways in which prolonged immersion in the field may affect the researcher. As an example, a number of writers have commented that ethnography presents researchers with particular ethical dilemmas (Gerrish, 2003; Johnson, 2003). The necessity of building rapport and trust with participants, whilst at the same time generating data from these same people 'raises issues of manipulation, exploitation and secrecy' (Walsh, 1998, p. 23). Gerrish (1997, p. 27) suggests that nurse researchers can reduce the potential dissonance between the dual role of nurse and researcher by offering a positive contribution to care rather than being merely an 'exploitive interloper'.

Another challenge in the use of ethnography as a research approach is the management of field roles and relationships. It is necessary to maintain a delicate balance between rapport in the field, whilst avoiding 'going native' by over identifying with participants. Hammersley, Atkinson (2007, p. 89) describe the need for the ethnographer to be 'poised between familiarity and strangeness'. Maintaining this may be stressful and, as noted earlier immersion in the field can be physically, mentally and emotionally tiring. However, despite these undoubted challenges posed by ethnography, we contend that as a research approach, it makes a valuable contribution to understanding nursing practice and work.

\section{Conclusion}

In drawing on these three ethnographies of nursing work, we have argued that adopting an ethnographic approach which uses multiple methods of data collection, but in particular the use of participant observation and prolonged immersion in the field is a powerful mechanism for obtaining insights into nursing practice. The realisation of this and how nurses adapt to and function within their particular context is important to understanding nursing practice as it is actually practised. Such understandings may facilitate changes in practice to improve patient care.

\section{Acknowledgment}

This paper was developed from a symposium presented at the Royal College of Nursing International Nursing Research Conference in Liverpool, UK. The authors wish to acknowledge the contribution of Dr Sue Philpin who conducted the study in the intensive therapy unit and her contribution to an early draft of this paper prior to her untimely death. 


\section{Literature}

Allen, D., 2004. Re-reading nursing and re-writing practice: towards an empirically based reformulation of the nursing mandate. Nursing Inquiry, 11(4), pp. 271-283. http://dx.doi.org/10.1111/j.1440-1800.2004.00234.x

PMid:15601415

Atkinson, P. \& Hammersley, M., 1994. Ethnography and participant observation. In: Denzin, N. \& Lincoln, Y. eds. Handbook of qualitative research. London: Sage, pp. 248-259.

Brewer, J. 2000. Ethnography. Buckingham: Open University Press, pp. 11-26.

Brink, P. \& Edgecombe, N., 2003. What is becoming of ethnography? Qualitative Health Research, 13(2), pp. 1028-1030. http://dx.doi.org/10.1177/1049732303253542

PMid:14502967

Delamont, S., 2007. Ethnography and participant observation. In: Seale, C., Gobo, G., Gubrium J. \& Silverman, D. eds. Qualitative research practice. London: Sage, pp. 205-217.

Geertz, C., 1993. The interpretation of cultures. London: Hutchinson, pp. 5-8.

Gerrish, K., 1997. Being a 'marginal' native: dilemmas of the participant observer. Nurse Researcher, 5(1), pp. 25-34.

Gerrish, K., 2003. Self and others: the rigour and ethics of insider ethnography. In: Latimer, J. ed. Advanced qualitative research in nursing. Oxford: Blackwell, pp. 77-94.

Gobo, G., 2008. Doing ethnography. Los Angeles: Sage, pp. 201-213.

Gold, R., 1958. Roles in sociological field observation. Social Forces, 36(3), pp. 217-223. http://dx.doi.org/10.2307/2573808

Green, J. \& Thorogood, N., 2013. Qualitative methods for health research. London: Sage, p. 23.

PMCid:PMC3707789

Griffiths, P., 2011. A community of practice: the nurses' role on a medical assessment unit. Journal of Clinical Nursing, 20 (1-2), pp. 247-254.

http://dx.doi.org/10.1111/j.1365-2702.2009.03135.x PMid:20626529

Hammersley, M. \& Atkinson, P., 2007. Ethnography: principles and practice. 3rd ed. London: Routledge, pp. 1-19.

Hammersley, M., 1992. What's wrong with ethnography? London: Routledge, pp. 5-10.
Holloway, I. \& Wheeler, S., 2010. Qualitative research in nursing. 3rd ed. Oxford: Blackwell Science, p. 153.

Johnson, M., 2003. Research ethics and education: a consequentialist view. Nurse Education Today, 23 (3), pp. 165-167. http://dx.doi.org/10.1016/S0260-6917(03)00017-0

PMid:12672383

Malinowski, B., 1922. Argonauts of the Western Pacific. London: Routledge, p. 81.

Mason, J., 1996. Qualitative Researching. Sage: London.

Mason, J., 2002. Qualitative Researching. 2nd ed. Sage: London.

Murphy, F. \& Merrell, J., 2009. Negotiating the transition: caring for women through the experience of early miscarriage. Journal of Clinical Nursing, 18(11), pp. 1583-1591.

http://dx.doi.org/10.1111/j.1365-2702.2008.02701.x

PMid:19490295

Nursing \& Midwifery Council (NMC), 2008. Code of conduct. London: Nursing \& Midwifery Council, pp. 2-10.

Philpin, S., 2007. Managing ambiguity and danger in an intensive therapy unit: ritual practices and sequestration. Nursing Inquiry, 14(1), pp. 51-59.

http://dx.doi.org/10.1111/j.1440-1800.2007.00354.x

PMid:17298608

Porter, S., 1995. Nursing's relationship with medicine: a critical realist ethnography. Aldershot: Avebury.

Prior, L., 2003. Using documents in social research. London: Sage.

Savage, J., 1995. Nursing intimacy: an ethnographic approach to nurse-patient interaction. London: Scutari.

Savage, J., 2000. Participative observation: standing in the shoes of others? Qualitative Health Research, 10(3), pp. 324-339. http://dx.doi.org/10.1177/104973200129118471

PMid:10947479

Smith, P., 1992. The emotional labour of nursing: how nurses care. London: Macmillan.

Street, A.F., 1992. Inside nursing: a critical ethnography of nursing practice. Albany: State University of New York Press.

Swanson, K.M., 1991. Empirical development of a middle range theory of caring. Nursing Research, 40(3), pp. 161-166.

http://dx.doi.org/10.1097/00006199-199105000-00008

PMid:2030995 
Swanson, K.M., 1999. Research-based practice with women who have had miscarriages. Image Journal of Nursing Scholarship, 31(4), pp. 339-345.

http://dx.doi.org/10.1111/j.1547-5069.1999.tb00514.x

PMid:10628100

Walsh, D., 1998. Doing ethnography. In: Seale, C. ed. Researching society and culture. London: Sage, pp. 217-232.

Watson, J., 1988. Human science and human care: a theory of nursing. New York: National League for Nursing.
Wilkins, R., 1993. Taking it personally: a note on emotion and autobiography. Sociology, 27(1), pp. 93-100.

http://dx.doi.org/10.1177/003803859302700109

Wolf, Z.R., 1988. Nurse's work, the sacred and the profane. Philadelphia: University of Pennsylvania Press.

Cite as/Citirajte kot:

Murphy, F., Griffiths, P. \& Merrell, J., 2014. The contribution of ethnography to understanding nursing work: a comparative review of three nursing ethnographies. Obzornik zdravstvene nege, 48(1), 12-20. http://dx.doi.org/10.14528/snr.2014.48.1.8 